\section{DE DE GRUYTER} OPEN
Przedsiębiorczość i Zarządzanie Entrepreneurship and Management University od Social Sciences Publishing House ISSN 1733-2486

Volume XVI, Issue 2, pp. 89-107

DOI 10.1515/eam-2015-0019

Michał Chmielecki

University of Social Sciences

Robert Seliga

University of Social Sciences

\title{
A Comparative Study of Attitudes towards Entrepreneurship between Polish and British Students
}

\begin{abstract}
Background

Entrepreneurship continues to gain momentum as a significant and relevant field of research. Policy makers in the rush to stimulate entrepreneurship in various countries, often rely on the success stories and prescriptions documented in the entrepreneurship literature in which most studies are set in the United States.
\end{abstract}

Research aims

The article present exploratory study addresses the subject of cross-cultural differences in attitudes towards entrepreneurship by focusing attention on two particular types of cultures of entrepreneurship British and Polish.

Method

The quantitative research (survey) was conducted in May 2014 among 153 Polish and 94 British graduate and postgraduate management students . 


\section{Key findings}

The findings have some distinctive implications for government, policy makers and educators through determining the attitudes towards entrepreneurship among students.

Key words: culture, entrepreneurship, attitudes, approaches, survey, analyses.

\section{Introduction and background}

While entrepreneurship is one of the most studied topics in economics and business research, findings have not been consistent regarding the attitudes towards and perceptions of entrepreneurship in different cultural and economic contexts.

However, entrepreneurship continues to gain momentum as a significant and relevant field of research. Policy makers in the rush to stimulate entrepreneurship in various countries, often rely on the success stories and prescriptions documented in the entrepreneurship literature. Given that most of the social science research in general, and entrepreneurship research in particular, has been generated in the U.S. and transferability to contexts where the task and psychic environments may be vastly different remains in question [Thomas, Shenkar, Clarke 1994, pp. 675-686]. International comparative studies of attitudes towards entrepreneurship are still quite rare.

\section{Entrepreneurship}

Entrepreneurs have already been described as the makers of new worlds [Czarniawaka \& Wolff 1991], innovators and catalysts of change who continuously do things that have not been done before and who do not fit established patterns [Schumpeter 1965]. They identify, assess, evaluate, manage and transfer risk [Deakins 1999]. Literature on entrepreneurs has stemmed from three main sources:

1. economic writers who stress the role of the entrepreneur in economic development;

2. social and business writers who stress the influence of the social and business environment on entrepreneurship;

3. psychologists who focus on the personality traits of entrepreneurs [Deakins 1999].

Academics have been defining characteristics of entrepreneurs for many years. See table 1. For the summary of this research. 
Table 1. Characteristics of entrepreneurs

\begin{tabular}{|c|c|c|}
\hline Date & Author/s & Characteristics \\
\hline 1848 & Mill & Risk bearing \\
\hline 1917 & Weber & Source of formal authority \\
\hline 1934 & Schumpeter & Innovation \\
\hline 1954 & Sutton & Desire for responsibility \\
\hline 1959 & Hartman & Source of formal authority \\
\hline 1961 & McClelland & $\begin{array}{l}\text { Risk taking, need for } \\
\text { achievement }\end{array}$ \\
\hline 1963 & Davids & $\begin{array}{l}\text { Ambition, desire for } \\
\text { independence }\end{array}$ \\
\hline 1964 & Pickle & Drive, human relations \\
\hline 1971 & Palmer & Risk measurement \\
\hline 1973 & Winter & Need for power \\
\hline 1974 & Borland & Internal locus of power \\
\hline
\end{tabular}

Source: based on J.A. Timmons, S. Spinelli (2007), New Venture Creation: Entrepreneurship for the 21st Century, 7/e, McGraw-Hill, Irwin.

At the same time the concepts of entrepreneurship have been changing. Most popular concepts are presented in table 2. 
Table 2. The concepts of entrepreneurship

\begin{tabular}{|l|l|}
\hline \multicolumn{1}{|c|}{ Author } & \multicolumn{1}{|c|}{ The concept of entrepreneurship } \\
\hline $\begin{array}{l}\text { R.W. Griffin } \\
\text { [1996, pp. 730- } \\
\text { 731] }\end{array}$ & $\begin{array}{l}\text { The process of organizing and running a business and } \\
\text { taking the risk involved and performing an active role in } \\
\text { management. }\end{array}$ \\
\hline $\begin{array}{l}\text { St.P. Robbins } \\
\text { D.A. DeCenzo } \\
\text { [2002, p. 104] }\end{array}$ & $\begin{array}{l}\text { The process of initiating business start up, organizing the } \\
\text { necessary resources and take risks in pursuit of the prize. }\end{array}$ \\
\hline $\begin{array}{l}\text { R.D. Hisrich } \\
\text { M.P. Peters } \\
\text { [1992, p. 10] }\end{array}$ & $\begin{array}{l}\text { The process of creating something different, because of its } \\
\text { value in the framework of which necessary time and effort is } \\
\text { devoted to achieve this goal, assuming the accompanying } \\
\text { financial, psychological and social risk, and expecting } \\
\text { obtaining financial rewards and personal satisfaction. }\end{array}$ \\
\hline $\begin{array}{l}\text { B. Piasecki } \\
\text { [2001, p. 25] }\end{array}$ & $\begin{array}{l}\text { Entrepreneurship is the process: } \\
\text { - which includes the action taken for the analysis } \\
\text { of opportunities of start and development (or just } \\
\text { development) of the venture, its financing and the possibility } \\
\text { of meeting the effects of such action; } \\
\text { - which can take many different forms and shapes, } \\
\text { including initiation of a venture, creativity and innovation } \\
\text { in developing new products or services, managing an } \\
\text { existing venture in such a way that it develops quickly and } \\
\text { continuously, seeking financial and material supply sources } \\
\text { for potentially growing number of ventures, accepting risk in } \\
\text { the development of new or expansion of existing ventures } \\
\text { these elements are the part of the entrepreneurial process, } \\
\text { although not all of them must participate in each activity). }\end{array}$ \\
\hline $\begin{array}{l}\text { F.L. Frey } \\
\text { 27-28] pp. }\end{array}$ & $\begin{array}{l}\text { Starting a venture and (or) its growth, which occurs through } \\
\text { the use of innovation, by management assuming the risk. }\end{array}$ \\
\hline
\end{tabular}




\begin{tabular}{|c|c|}
\hline $\begin{array}{l}\text { J. Penc } \\
{[1997, \text { p. 335] }}\end{array}$ & $\begin{array}{l}\text { The behavior of a person or organization that relies on } \\
\text { seeking and applying new solutions, which require more } \\
\text { energy, initiative and resourcefulness and the ability to } \\
\text { estimate the necessary effort and possible benefits available } \\
\text { under existing constraints and opportunities, and the } \\
\text { willingness to take risk and responsibility for their decisions } \\
\text { and actions. }\end{array}$ \\
\hline $\begin{array}{l}\text { J. Timmons } \\
{[1990, \text { p. } 5]}\end{array}$ & $\begin{array}{l}\text { The process of creating or identifying opportunities and } \\
\text { using them despite of their current resources (...). It is } \\
\text { an creative act of an entrepreneur who finds in him and } \\
\text { devotes enough energy to initiate and build a company or } \\
\text { organization, rather than just observe, analyze and describe } \\
\text { it. }\end{array}$ \\
\hline $\begin{array}{l}\text { N. Churchill } \\
{[1983, \text { p. } 27]}\end{array}$ & $\begin{array}{l}\text { The process of discovery and development of capabilities } \\
\text { to create new value through innovation, acquisition of } \\
\text { necessary resources and managing the process of value } \\
\text { creation. }\end{array}$ \\
\hline $\begin{array}{l}\text { J.A. Schumpeter } \\
{[1960, \text { p. 60] }}\end{array}$ & $\begin{array}{l}\text { Recognizing opportunities for implementation of ventures } \\
\text { that are profitable and risk-taking to implement them. }\end{array}$ \\
\hline $\begin{array}{l}\text { W. Adamczyk } \\
\text { [1996] }\end{array}$ & $\begin{array}{l}\text { An organized sequential process oriented under certain } \\
\text { circumstances at using innovative idea in order to generate } \\
\text { benefits in the market. }\end{array}$ \\
\hline $\begin{array}{l}\text { S. Sudoł } \\
{[2002, \text { p. 33] }}\end{array}$ & $\begin{array}{l}\text { Feature (way of behaving) of entrepreneurs and companies, } \\
\text { that means the willingness and ability to undertake and } \\
\text { solve creative and innovative new problems, while taking } \\
\text { into consideration its risks, the ability to use the available } \\
\text { opportunities and flexibility to adapt to changing conditions }\end{array}$ \\
\hline $\begin{array}{l}\text { T. Kraśnicka } \\
{[1999, \text { p. 98] }}\end{array}$ & $\begin{array}{l}\text { Entrepreneurship is an activity that stands out by: activity } \\
\text { and dynamism, innovation, looking for changes and reacting } \\
\text { to them, perceiving opportunities and their use, regardless } \\
\text { of the resources (at the moment), willingness to take risks, } \\
\text { which main motive is to multiply the capital. }\end{array}$ \\
\hline
\end{tabular}

Source: A.S. Thomas, O. Shenkar, L.D. Clarke (1994); Griffin R.W. (1996); Robbins St.P., DeCenzo D. (2002); Hisrich R.D., Peters M.P. (1992); Piasecki B. (red.). (2001); Frey R.F. (1993); Penc J. (1997); Timmons J. (1990); Churchill N., Levis V. (1983); Schumpeter J.A. (1960); Adamczyk W. (1996); Sudoł St. (2002) Cit. 's. Ł. Sułkowski, Barriers to entrepreneurship in the management of hospitals in Poland, L'entrepreneur face aux politiques publiques europeennes, ed. C. Martin, T. Rkibi, PGV/ ISLA, Lisboa 2012. 
Since the early 1980s, entrepreneurship has emerged as a topic of growing interest among management scholars and social scientists. The subject has recently grown in legitimacy, particularly in business schools [Cooper 2005]. This interest has been spurred by a set of recent developments in the United States: the vitality of start-up firms in high technology industries, the expansion of venture capital financing, and the successes of regional clusters, notably Silicon Valley. Management scholars and social scientists interested in entrepreneurship have tended to focus their attention on studying new business formation. Unfortunately not much on differences between Polish and British attitudes towards entrepreneurship has been published so far.

\section{Forces shaping attitude towards entrepreneurship}

There are several forces shaping attitudes towards entrepreneurship.

For instance studies have shown that entrepreneurs grew up in families where the father was self-employed [Cooper \& Gimeno 1992; Cromie, Callaghan, \& Jansen 1992] and where the family was involved and supported early start-up activities [Carroll \& Mosakowski 1987; Huisman 1985] found significant variation in entrepreneurial activity across cultures and indicated that cultural values greatly influence entrepreneurial behavior.

McGrath, MacMillan, and Scheinberg [1992] in their comparison of entrepreneurs and non-entrepreneurs found significant differences in cultural values and beliefs. There is numerous research indicating that culture affects entrepreneurship. Lent et al. [2000] for instance suggest that the immediate personal environment (e.g., close family) as well as the broader socio-cultural context (e.g., national culture) can influence an individual's career choice. With regard to entrepreneurial career decisions culture can influence entrepreneurial intentions through social norms.

Culture is defined as a set of shared values, beliefs, and expected behaviors [Hofstede 1980a]. Hofstede [1980] and House et al. [2004] think that cultural characteristics exert a significant effect on the characteristics of the organizations in that society.

Hofstede's dimensions analysis can help in better understanding the intercultural differences within regions and between countries in attitudes towards entrepreneurship. There are several dimensions developed by Hofstede.

"On the one side versus its opposite, collectivism, that is the degree to which individuals are integrated into groups. On the individualist side we find societies in which the ties between individuals are loose: everyone is expected to look 
after him/herself and his/her immediate family. On the collectivist side, we find societies in which people from birth onwards are integrated into strong, cohesive in-groups, often extended families (with uncles, aunts and grandparents) which continue protecting them in exchange for unquestioning loyalty. The word 'collectivism' in this sense has no political meaning: it refers to the group, not to the state. Again, the issue addressed by this dimension is an extremely fundamental one, regarding all societies in the world" [http://www. geert-hofstede.com/index.shtml; accessed: 5.08.2014].

People from individualistic cultures are interested in their own freedom and goals and their own individual growth and achievements and show relatively little engagement in a group life. That is why in business environment, such people are expected to work on their own, often in accordance with their own interest.

Power distance shows the degree to which people from a certain culture accept or do not accept the inequality power of authority, hierarchy and differences in statuses. The high power distance cultures accept the hierarchy as a norm, when low power distance cultures try to maintain their society more equal in status and power. The high indication of power distance score of a culture defines this culture as hierarchically structured and authority accepting. In business environment, the power distance dimension shows to which extend people would accept the supervision, obey the authorities and follow the hierarchical scale. People from low power distance cultures, expect to be considered and treated equally as their supervisors or managers. They do not like to be regarded as the subordinates, moreover, they expect to work in a team, where everyone has the same rights and everyone works hard as others in order to reach the common goal [Hofstede and Hofstede 2005, p. 46].

Masculinity helps to define and explain the roles of genders in different cultures. In masculine societies men are strongly believed to be ambitious, aggressive, confident and domineering. They are expected to concentrate on the gain of material goods, when women, on contrary are expected to be family oriented and focused on interpersonal relations, as they must be modest and reserved. In masculine cultures men are expected to be more focused on achieving professional goals rather than women, because women are expected to take care of a family and home [Hofstede and Hofstede 2005, p. 402].

The uncertainty avoidance index deliberates the degree to which people feel threatened and insecure in the new, uncertain and ambiguous situations. Those cultures with the high score in the uncertainty avoidance try to avoid new and different from the usual situations. In contrast, people from the cul- 
tures with the low score in UAI are not afraid of new, unclear and indefinite situations. In low uncertainty avoidance cultures, people prefer unregulated pace of work, not structured processes and less control from the manager, while they feel uncomfortable with strictly arranged rules, structures and policies. They need to feel some kind of freedom to undertake the new task, new challenge for their personal satisfaction, even if they are not expected to do so [Hofstede and Hofstede 2005 p.184].

The long-term orientation dimension can be interpreted as dealing with society's search for virtue. Societies with a short-term orientation generally have a strong concern with establishing the absolute Truth. They are normative in their thinking. They exhibit great respect for traditions, a relatively small propensity to save for the future, and a focus on achieving quick results. In societies with a long-term orientation, people believe that truth depends very much on situation, context and time. They show an ability to adapt traditions to changed conditions, a strong propensity to save and invest, thriftiness, and perseverance in achieving results. Long term orientation refers to the fostering of virtues that are oriented toward future rewards. Short-term orientation emphasizes the past and present, in particular with respect to traditions, preservation of "face", and social obligation" [Hofstede and Hofstede 2005, p. 210].

Indulgence versus restraint is the sixth cultural dimension studied and elaborated by Hofstede and Michael Minkov in 2010. Hofstede defines Indulgence and Restraint as a tendency to allow relatively free gratification of basis and natural human desires related to enjoying life and having fun. Restraint: a conviction that such gratification needs to be curbed or regulated by strict social norms [http://www.geert-hofstede.com/index.shtml; accessed: 5.08.2014].

Normative versus pragmatic. People in normative such societies have a strong concern with establishing the absolute Truth. They exhibit great respect for traditions, a relatively small propensity to save for the future and a focus on achieving quick results. In pragmatic orientation societies, people believe that truth depends very much on situation, context and time. They show an ability to adapt traditions easily to changed conditions, a strong propensity to save and invest, thriftiness and perseverance in achieving results [http:// www.geert-hofstede.com/index.shtml; accessed: 5.08.2014]. 


\section{Picture 1. Hofstede dimensions - Poland and the UK}

\section{The comparison between Poland and the UK looks as follows (see picture 1).}

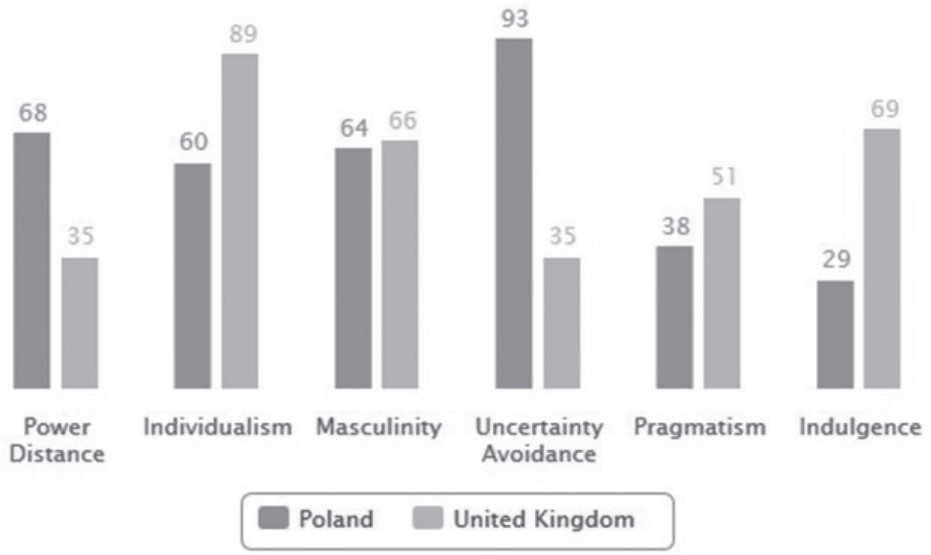

Source: http://geert-hofstede.com/poland.html.

In many of the aforementioned definitions, the following variables describe entrepreneurship as:

1. The process of innovative and creative markets activities or organizational changes (technological and organizational innovation),

2. Taking risks in business or tolerance of uncertainty aiming at the development of the venture (the tendency to act under uncertainty),

3. Flexibility in relation to strategy and market activities and the willingness to change and intraorganizational flexibility (market and organizational flexibility),

4. Exploration and exploitation of opportunities inherent in the environment of the organization and the unique competitive advantages of having support in the organizational resources (exploration opportunities)

5. The set of entrepreneurial characteristics such as innovation, creativity, willingness to take risks, and orientation to change (the entrepreneurial personality) [Sułkowski 2012, pp. 382-398]. It's worth stressing that all of that variables depend on culture especially on one particular dimension called by Hofstede uncertainty avoidance index.

Numerous researchers acknowledge the importance of the cultural context for career decisions [e.g. Lent, Brown \& Hackett 2000; Flores, Robitschek, Celebi, Andersen \& Hoang 2010; Leong 2010]. 
Hayton, George, and Zahra [2002] stress that cultural values serve as a filter for the degree to which a society considers certain entrepreneurial behaviors as desirable. Hence, numerous authors have emphasized the importance of understanding the impact of cultural norms on entrepreneurship.

Unconscious, deeply embedded and even irrational shared values shape the way people perceive entrepreneurs and entrepreneurship. Cultural values indicate the degree to which a society considers entrepreneurial behaviors, such as risk taking or independent thinking, to be desirable. Cultures that value such behaviors promote a propensity to develop and introduce innovation, whereas cultures that reinforce conformity, group interests, and control over the future are not likely to show risk-taking and entrepreneurial behavior. Therefore, it is important to understand the research on national culture and its potential influence on entrepreneurship.

McClelland predicted that cultures which valued achievement orientations would exhibit higher levels of entrepreneurship. Even examples of personality dimensions believed to be culturally determined include innovativeness, locus of control, risk-taking, energy level [Thomas \& Mueller, 2000].

Authors believe that the most important areas influencing attitudes towards entrepreneurship in international comparative context will concern:

- culture (shaping among others entrepreneurial intentions (including career choice), attitude towards risk taking, perceptions of own skills and abilities,

- country's infrastructure allowing entrepreneurs to relatively easy start their business

That led us to creation of 5 research questions:

- RQ 1 Do Polish and British students vary in terms of their perception on their entrepreneurial abilities and skills i.e. whether they believe they have the skill and capabilities required to succeed as an entrepreneur?

- RQ2 Do Polish and British students vary in terms of their perception on, chances of establishing their own business?

- RQ 3 Do Polish and British students vary in their perceptions regarding the ease of starting a firm?

- RQ 4 Whether both groups consider entrepreneurship to be highly desirable career alternative for people with their education?

- RQ 5Whether both groups consider starting a firm as the best way to take advantage of their education? 


\section{Methodology}

Empirical illustration of the approach of Polish and British students to the issues of entrepreneurship was based on quantitative research carried out in Poland and the UK among Polish and British students. It should be noted that this is the pilot study and the results cannot be generalized.

The research was conducted in May 2014. Participants in this study are 247 students 6 Universities in 2 different countries. Tables 1-3 show sample characteristics. The sample from Poland (Warszawa, Łódź, Kraków, Poznań) consisted of 153 graduate and postgraduate students, the sample from the UK (London, Leeds, Edinburgh), consisted of 94 graduate and postgraduate students.

Table 1. Characteristics of the respondents - location

\begin{tabular}{|c|c|c|c|}
\hline Lp. & Location & Number of respondents & Percentage \\
\hline 1 & Poland & 153 & $62 \%$ \\
\hline 2 & Great Britain & 94 & $38 \%$ \\
\hline \multicolumn{2}{|c|}{ Total: } & 247 & $100 \%$ \\
\hline
\end{tabular}

Source: own study based on the research.

Table 2. Characteristics of the respondents - age

\begin{tabular}{|c|c|c|c|}
\hline Lp. & Age & Number of responfents & Percentage \\
\hline 1 & $19-25$ & 99 & $40 \%$ \\
\hline 2 & $26-35$ & 86 & $35 \%$ \\
\hline 3 & over 35 & 62 & $25 \%$ \\
\hline \multicolumn{2}{|c|}{ Total: } & 247 & $100 \%$ \\
\hline
\end{tabular}

Source: own study based on the research.

Table 3. Characteristics of the respondents - sex

\begin{tabular}{|c|c|c|c|}
\hline Lp. & Sex & Number of responfents & Percentage \\
\hline 1 & Female & 149 & $60 \%$ \\
\hline 2 & Male & 98 & $40 \%$ \\
\hline \multicolumn{2}{|c|}{ Total: } & 247 & $100 \%$ \\
\hline
\end{tabular}

Source: own study based on the research. 
In this paper we addressed several questions:

- RQ 1 Do Polish and British students vary in terms of their perception on their entrepreneurial abilities and skills i.e. whether they believe they have the skill and capabilities required to succeed as an entrepreneur.

Table 4. Perception of Polish and British students

\begin{tabular}{|l|l|c|c|c|c|c|}
\hline Nationality & \multicolumn{1}{|c|}{$\begin{array}{r}\text { Research } \\
\text { question }\end{array}$} & $\begin{array}{c}\text { I fully } \\
\text { aggree }\end{array}$ & I agree & $\begin{array}{c}\text { I don't } \\
\text { know }\end{array}$ & $\begin{array}{c}\text { I don't } \\
\text { agree }\end{array}$ & $\begin{array}{c}\text { I fully } \\
\text { disagree }\end{array}$ \\
\hline Polish & $\begin{array}{l}\text { I have the skill } \\
\text { and capabilities } \\
\text { required to } \\
\text { succeed as an } \\
\text { entrepreneur }\end{array}$ & $7 \%$ & $8 \%$ & $50 \%$ & $23 \%$ & $12 \%$ \\
\hline British & $\begin{array}{l}\text { I have the skill } \\
\text { and capabilities } \\
\text { required to } \\
\text { succeed as an } \\
\text { entrepreneur }\end{array}$ & $45 \%$ & $41 \%$ & $10 \%$ & $3 \%$ & $1 \%$ \\
\hline Polish & $\begin{array}{l}\text { I am confident } \\
\text { that I would } \\
\text { succeed if } \\
\text { I started a firm }\end{array}$ & $10 \%$ & $15 \%$ & $40 \%$ & $27 \%$ & $7 \%$ \\
\hline British & $\begin{array}{l}\text { I am confident } \\
\text { that I would } \\
\text { succeed if } \\
\text { I started a firm }\end{array}$ & $49 \%$ & $39 \%$ & $11 \%$ & $1 \%$ & $0 \%$ \\
\hline British & $\begin{array}{l}\text { It would be } \\
\text { comparatively } \\
\text { easy for me to } \\
\text { start a firm }\end{array}$ & $8 \%$ & $24 \%$ & $48 \%$ & $14 \%$ & $6 \%$ \\
\hline $\begin{array}{l}\text { It would be } \\
\text { comparatively } \\
\text { easy for me to } \\
\text { start a firm }\end{array}$ & $54 \%$ & $44 \%$ & $2 \%$ & $0 \%$ & $0 \%$ \\
\hline
\end{tabular}




\begin{tabular}{|l|l|l|l|l|l|l|}
\hline Polish & $\begin{array}{l}\text { I personally } \\
\text { consider } \\
\text { entrepreneurship } \\
\text { to be highly } \\
\text { desirable career } \\
\text { alternative for } \\
\text { people with } \\
\text { mu educational } \\
\text { background }\end{array}$ & $15 \%$ & $12 \%$ & $41 \%$ & $25 \%$ & $7 \%$ \\
\hline British & $\begin{array}{l}\text { I personally } \\
\text { consider } \\
\text { entrepreneurship } \\
\text { to be highly } \\
\text { desirable career } \\
\text { alternative for } \\
\text { people with } \\
\text { mu educational } \\
\text { background }\end{array}$ & $51 \%$ & $44 \%$ & $4 \%$ & $1 \%$ & $0 \%$ \\
\hline British & $\begin{array}{l}\text { Starting a firm for } \\
\text { me would be the } \\
\text { best way to take } \\
\text { advantage of my } \\
\text { education }\end{array}$ & $18 \%$ & $23 \%$ & $44 \%$ & $10 \%$ & $5 \%$ \\
\hline $\begin{array}{l}\text { Starting a firm for } \\
\text { me would be the } \\
\text { best way to take } \\
\text { advantage of my } \\
\text { education }\end{array}$ & $55 \%$ & $39 \%$ & $3 \%$ & $2 \%$ & \\
\hline
\end{tabular}

Source: own study based on the research. 


\section{Discussion}

Although a college degree program builds critical skills, few coll1 eges and universities can fully prepare students for real-world challenges. Despite the substantial pressure to make good grades and to complete assignments on time, few college experiences can match the demands of a regular, full-time job and especially the career of an entrepreneur. Polish education system stresses theoretical aspects which give the students the perception that it would be better for them to start as an employee first, gain practical experience and then try to fulfill as an entrepreneur.

It is worth stressing here the role of uncertainty and risk. One can measure the attitude to risk is by looking at public tolerance when offering a second chance to people who failed to set up a successful business. However, according to Eurobarometer 2012 on entrepreneurship people in both countries seem to be quite understanding towards failing entrepreneurs and agree that they should be given a second chance.

RQ2 Do Polish and British students vary in terms of their perception on, chances of establishing their own business.

It comes as no surprise that entrepreneurs are rather an optimistic social group. Optimism can help entrepreneurs persist in the face of a challenge. They results were not surprising at all. Complaining about the future of the country is a long-standing Polish tradition. There's an old joke about a Polish optimist meeting a Polish pessimist: "Things are so bad, so terribly bad, that they couldn't possibly get any worse", says the pessimist, to which the optimist replies: "Don't worry my friend, they could, they really could". In Polish society where pessimism is a bit high [Gładziuk 2014], there is a tendency to get discouraged or rather not encouraged to venture into business because of fear of failing, especially when the risk is high. The opposite obtains in the UK and where the attitude, individual desire and strong optimistic approach were significant features.

What is more people from the "more individualistic" countries of Western Europe (see picture 1.) consider themselves as autonomous, more differentiated from others and independent from social groups, compared with people in "more collectivistic" countries. The Eastern European countries and Asia are considered a bit more collectivistic, and people tend to perceive themselves using a sociocentric perspective, which is socially sensitive, more interdependent and less differentiated, i.e. pursuing group rather than personal goals [Markus \& Kitayama 2003; Oyserman \& Lee 2008]. That influences the desire and 
readiness to be either a part of an organization or becoming independent as an entrepreneur.

RQ 3Would it be comparatively easy for both of the groups to start a firm?

The answers in a way confirm ease of doing business index. The ease of doing business index is an index created by the World Bank. Higher rankings indicate better, usually simpler, regulations for businesses and stronger protections of property rights. Empirical research funded by the World Bank to justify their work show that the effect of improving these regulations on economic growth is strong. As one can see Poland ranks 45 and the UK ranks 10 .

Table 5. Ease of doing business index - chosen countries

\begin{tabular}{|c|c|c|c|c|c|c|c|c|c|}
\hline 2014 & 2013 & 2012 & 2011 & 2010 & 2009 & 2008 & 2007 & 2006 & Country/region \\
\hline 1 & 1 & 1 & 1 & 1 & 1 & 1 & 1 & 1 & Singapore \\
\hline 2 & 2 & 2 & 2 & 2 & 2 & 4 & 4 & 4 & Hong Kong \\
\hline 3 & 3 & 3 & 3 & 3 & 3 & 2 & 2 & 2 & New Zealand \\
\hline 4 & 4 & 4 & 5 & 4 & 4 & 3 & 3 & 3 & United States \\
\hline 5 & 5 & 5 & 6 & 6 & 5 & 5 & 6 & 6 & Denmark \\
\hline$\ldots$ & $\ldots$ & $\ldots$ & $\ldots$ & ... & $\ldots$ & ... & $\ldots$ & ... & $\ldots$ \\
\hline 10 & 7 & 7 & 4 & 5 & 6 & 6 & 5 & 5 & United Kingdom \\
\hline$\ldots$ & $\ldots$ & $\ldots$ & $\ldots$ & $\ldots$ & $\ldots$ & $\ldots$ & $\ldots$ & $\ldots$ & $\ldots$ \\
\hline 41 & 39 & 35 & 34 & 34 & 32 & 35 & 31 & 30 & South Africa \\
\hline 42 & 43 & 41 & 36 & 56 & 65 & 54 & 51 & 55 & Peru \\
\hline 43 & 45 & 42 & 39 & 37 & 49 & 67 & 74 & 63 & Colombia \\
\hline 44 & 51 & 56 & 66 & 71 & 77 & 80 & 72 & .. & Montenegro \\
\hline 45 & 55 & 62 & 70 & 72 & 72 & 71 & 64 & 56 & Poland \\
\hline
\end{tabular}

Source: World Bank. 
Polish students far stronger believe that it is difficult for a local entrepreneur to open and run a small to medium size business.

Additionally it can be suggested that Polish tendency to complain discourages young people form starting setting up their ventures. It is suggested that the immediate personal environment (e.g., significant others) as well as the broader socio-cultural context (e.g., societal culture) influence and affect entrepreneurship process. Specifically, the broader socio-cultural context is assumed to exert its influence through the immediate personal environment on entrepreneurship and career choice decisions.

It is also worth stressing that entrepreneurship rate is negatively related to individualism when development is medium or low, and positively related to individualism when the level of development is high (case of UK) [ María-José Pinillos, Luisa Reyes, 2011].

RQ 4 Whether both groups consider entrepreneurship to be highly desirable career alternative for people with their education.

It is clearly visible that both groups differ considerably. On the one hand British students are increasingly disenchanted with career prospects as organizational employees. Fierce competition, cost-cutting pressures, and leveraged buyouts have resulted in corporate restructurings that have undermined such traditional values as employee loyalty, security, and ownership of results on the other hand results show that Polish students desire work which provides a feeling of accomplishment, job security, and the opportunity to acquire knowledge and skills. One must admit that self-employment as a proportion of total UK employment is especially high in comparison with other OECD countries [Blanchflower 2000, 2005] especially with Poland.

RQ 5 Whether both groups consider starting a firm as the best way to take advantage of their education?

Here again, in case of Poland it can be explained by too theoretical models of higher education. Students believe they can use their knowledge well when being guided and mentored by real managers or business owners. They believe they need some sort of incubation. Bringing entrepreneurs in to help design curricula especially MBA programmes or undergraduate business degrees, would provide the training they need to solve real, current problems through companies of their own. 


\section{Summary}

Entrepreneurship is being recognized as an important factor for economic growth and the regeneration of economies. The decision to start a venture has both cultural and economic dimensions. The importance of different cultural dimensions and their effects on entrepreneurship has been noted in a numerous studies. This paper has attempted to explore the attitudes towards entrepreneurship between Polish and British students.

The findings have some distinctive implications for Polish government, policy makers and educators through determining the attitudes towards entrepreneurship among Polish students. High or moderately high entrepreneurial attitudes of the students require a long-term planning and policy making to facilitate new venture creation for younger generation through providing the funds and infrastructures as well as removing the impediments on the path to become an entrepreneur and fostering entrepreneurial culture.

\section{References}

Adamczyk W. (1996), Przedsiębiorczośc: próba systematyki, „Przegląd Organizacji”, nr 2.

Blanchflower D.G. (2000), Self-employment in OECD countries, "Labour Economics", 7, September, pp. 471-505.

Blanchflower D.G., Wainwright (2005), An analysis of the impact of affirmative action programs on self-employment in the construction industry, NBER Working Paper.

Carroll G.R., Mosakowski E. (1987), The career dynamics of self employment, "Administrative Science Quarterly”, 32, pp. 570-89.

Churchill N., Levis V. (1983), The Five Stages of Small Business Growth, "Harvard Business Review", May-June, p. 27.

Cooper A.C., Gimeno G.F.J. (1992), Entrepreneurs, processes of founding and new firm performance [in:] D.L. Sexton, J.D. Kasarda (eds), The State of the Art of Entrepreneurship (pp. 301-40), Boston: Kent Publishing Co.

Cromie S., Callaghan I., Jansen M. (1992), The entrepreneurial tendencies of managers: A research note, "British Journal of Management", 3: 1-5.

Czarniawaka J.B., Wolff R. (1991), Leaders, managers, entrepreneurs on and off the organizational stage, "Organization Studies", 12: 529-46.

Deakins D. (1999), Entrepreneurship and Small Firms, London: McGraw-Hill. 
Flores L.Y., Robitschek C., Celebi E., Andersen C., Hoang U. (2010), Social cognitive influences on Mexican Americans' career choices across Holland's themes, "Journal of Vocational Behavior", 76, 198-210.

Frey R.F. (1993), Enterprenaurship: A Planing Approach, West Publishing Company, pp. 27-28.

Gładziuk N. (2014), Cultural Pessimism And Heroic Manliness

"Kultura i Spoleczenstwo", Volume 58, Issue 1, Pages 3-19, ISSN (Online) 2300195X.

Griffin R.W. (1996), Podstawy zarzadzania organizacjami, PWN, Warszawa, ss. 730-731.

Hayton J.C., George G., Zahra S.A. (2002), National culture and entrepreneurship: A review of behavioral research, "Entrepreneurship Theory and Practice", 26(4), $33-52$.

Hisrich R.D., Peters M.P. (1992), Entrepreneurship. Starting, Developing and Managing a New Enterprise, 2nd. Ed., IRWING, Boston, p. 10.

Hofstede G. (1980), Culture's consequences: International differences in work-related values, Beverly Hill, CA: Sage Publications.

Hofstede G., Hofstede G.J. (2005), Cultures and Organizations Software of the Mind, McGraw Hill, New York.

House R.J., Hanges P.J., Javidan M., Dorfman P.W., Gupta, V. (Eds.). (2004), Culture, leadership and organizations: The GLOBE study of 62 societies, Thousand Oaks, CA: Sage Publications.

Huisman D. (1985), Entrepreneurship: Economic and cultural influences on the entrepreneurial climate, "European Research", 13(4), 10-17.

Lent R.W., Brown S.D., Hackett G. (2000), Contextual supports and barriers to career choice: A social cognitive analysis, "Journal of Counseling Psychology", 47 (1), 36-49.

Leong F.T.L. (2010), A Cultural Formulation Approach to Career Assessment and Career Counseling: Guest Editor's Introduction, "Journal of Career Development", 37, 375-390.

McGrath R.G., MacMillan I.C., Scheinberg S. (1992), Elitists, risk-takers, and rugged individualists? An exploratory analysis of cultural differences between entrepreneurs and non-entrepreneurs, "Journal of Business Venturing", 7, 115-135.

Penc J. (1997), Leksykon biznesu. Biblioteka biznesmena, Placet, Warszawa, s. 335.

Piasecki B. (red.) (2001), Ekonomika i zarzadzanie mata firma, PWN, WarszawaŁódź, s. 25. 
Pinillos María-José A., Reyes Luisa A. (2011), Relationship between individualistcollectivist culture and entrepreneurial activity: evidence from Global Entrepreneurship Monitor data, „Small Business Economics”, V. 37, N 1, pp. 23-37.

Robbins St.P., DeCenzo D. (2002), Podstawy zarzadzania, PWE, Warszawa, p. 104.

Schumpeter J.A. (1960), Teoria rozwoju gospodarczego, PWN, Warszawa, p. 60.

Sudoł St. (2002), Przedsiębiorstwo, Podstawy nauki o przedsiębiorstwie. Teorie i praktyka zarzadzania, TNOiK, Toruń, p. 33.

Sułkowski Ł. (2012), Barriers to entrepreneurship in the management of hospitals in Poland, L'entrepreneur face aux politiques publiques europeennes, ed. C. Martin, T. Rkibi, PGV/ ISLA, Lisboa.

Thomas A.S., Mueller S.L. (2000), A case for comparative entrepreneurship:Assessing the relevance of culture, "Journal of International Business Studies", 31(2), pp. 287-301.

Thomas A.S., Shenkar O., Clarke L.D. (1994), The globalization of our mental maps: Evaluating the geographic scope of JIBS coverage, "Journal of International Business Studies", 25(4): 675-686.

Timmons J. (1990), New Venture Creation, IRVIN, Boston, p. 5.

www.geert-hofstede.com (access 5.08.2014). 